\author{
STANISLAV P̌̌IBYL \\ University in České Budějovice, Czech Republic \\ (D) https://orcid.org/0000-0002-2470-1405
}

\title{
Participative Decision Making of the Faithful in the Church
}

\begin{abstract}
The life of the primitive church, to this day, reflects the authenticity of the Church's practices and its inner arrangement. As such, this article discusses the possibilities of the inner life and order of ecclesiastical communities in the most ancient times of the Church. It does not, however, question the significance of the role of the leading figures within the Church, as it corresponds with concrete pleas to the faithful for obedience, as already mentioned within New Testament writings, likewise does so the institution of the monarchical bishop, as propagated by the epistles of Ignatius of Antioch. However, Luke's Acts of the Apostles do, for example, contain testimonials of the participation of the entire ecclesiastical community on the appointing of Apostle Matthias and the first seven deacons. Didache, the early Christian treatise, does too, on one note, stress the importance of the carriers of the prophetic charism, nonetheless it does offer ecclesiastical communities with certain criteria regarding their participation on the service of said charismatics, and their assessments thereof. The Gospel of Matthew, along with Paul's first Epistle to the Corinthians, point towards participation of all the members of the ecclesiastical communities on the execution of essential penal measures against convicted Christians.
\end{abstract}

Keywords: Church, apostle, presbyter, deacon, prophet, procedure, election, discipline, punishment

\section{Authority of Monarchical bishops in harmony with their associates}

It is evident that for a bearer of any form of authority, not excluding one of Ecclesiastical authority, it is far more convenient if they are to be 
the sole executer of power invested within them, with all their subjects having, at the most, an advisory role. A symbolic expression of this convenience is the amendment to the canon law, regarding the authority of bishops to appoint to subordinate offices. For this, the legislators of the Code of canon law, were satisfied with defining one single and concise canon: "Unless the law expressly states otherwise, it is the prerogative of the diocesan Bishop to make appointments to ecclesiastical offices in his own particular Church by free conferral (libera collatione)." Here, the canon law, correspondingly provides for the appropriate maximization of the responsibilities of the said ecclesiastical authority. ${ }^{2}$ In comparison, the rules regarding canonical elections number a staggering sixteen canons, and in detail define the entire electoral process. ${ }^{3}$ The preference of the Catholic Church for sovereign decision making of responsible higher ecclesiastical authorities has many external and internal causes, both of a historical, and a theological nature. Today, the hierarchically arranged Catholic Church may be forced to exhibit forms of collective decision making, which does not correspond to her internal structure and ecclesiology. For example, the Swiss cantons do not acknowledge any nondemocratically organized religious societies. For that reason they created for the Church democratically structured corporations which are to be at the Church's disposal. Thus, the participation of the faithful in the decision-making processes within the Church is forced by an external secular power. ${ }^{4}$

The accentuation of the authority of the individual within the Catholic Church involves two main ecclesiastical services: the bishop and the Roman Pontiff. The monarchical episcopate, whose greatest apologist in the early Church was the bishop and martyr Ignatius of Antioch, chiefly signifies that the bishop has full responsibility within his local Church. Also, according to the current canon law, other clerics and laity involved in various diocesan councils and boards cooperate with the bishop on forming pastoral strategies, nevertheless this cannot be known as participative decision making, since the definitive burden of decision making

1 CIC/1983, Canon 157.

2 "Free will to appoint, belongs to all who are authorise to establish, adjust, or terminate an office, which they appointed (cf. can. 148). On the level of the universal Church it applies, without exception, to the Roman pontiff. On the level of local churches, it applies to the Roman pontiff and lower authorities, be it regional, such as a diocesan bishop, or personal, such as higher superiors of religious orders." J. GARCía Martín: Le norme generali del Codex Iuris Canonici. Roma 1996, p. 557.

${ }^{3}$ Cf. CIC/1983, cann. 164-179.

4 "This tends to be described as a dualistic system. The Cantons transfer a portion of their tax jurisdiction on to this parachurch organisation." Ch. Winzeler: Einführung in das Religionsverfassungsrecht der Schweiz. Zürich 2009, p. 51. 
and responsibilities tied to said decision making lie solely upon the shoulders of the bishop: "By divine institution, Bishops succeed the Apostles through the Holy Spirit who is given to them. They are constituted Pastors in the Church, to be the teachers of doctrine, the priests of sacred worship and the ministers of governance." 5

At the beginning of the 2nd century $\mathrm{AD}$, Ignatius of Antioch stresses not only the sovereignty of the bishop's decision making, but as well the importance for the cooperation of all other members of the Church with the bishop. His epistles do not yet specify the mechanisms through which associates assisted in the bishop's decision-making process. However, the richly structured life of ecclesial communities must take place in inner and mutual harmony: "Thus it is proper for you to run together in harmony with the mind of the bishop, as you are in fact doing. For your council of presbyters, which is worthy of its name and worthy of God, is attuned to the bishop as strings to a lyre. Therefore, in your unanimity and harmonious love Jesus Christ is sung." ${ }^{6}$ This unity of believers in the organically organized structure of the Church is at the same time a manifestation of a deeper spiritual reality which is aptly expressed by a musical metaphor: "You must join this chorus, every one of you, so that by being harmonious in unanimity and taking your pitch from God you may sing in unison with one voice through Jesus Christ to the Father, in order that he may both hear you and, on the basis of what you do well, acknowledge that you are members of his Son. It is, therefore, advantageous for you to be in perfect unity, in order that you may always have a share in God." Here we can recognize a sign of the Paulian concept of the relationship between Christ's body and the limbs of his Church, although similar comparison is also not distant from the period Judaic literature, as evidenced by the meditation on the bravery of the martyrs in the fourth book of Maccabees: "Just as the hands and feet are moved in harmony with the guidance of the mind, so those holy youths, as though moved by an immortal spirit of devotion, agreed to go to death for its sake."

If the bishop's office is monarchical, the services of presbyters and deacons everywhere show collegial features; Ignatius always mentions them in the plural in contrast to the bishop, which corresponds to the state already recorded in the Pastoral Epistles. ${ }^{9}$ It is clear that both groups were

${ }^{5}$ CIC/1983, can. 375 § 1 .

${ }^{6}$ IgnEph. 4:1.

7 IgnEph. 4:2.

84 Macc. 14:6.

9 'In the pastoral epistles, the 'bishop' is always spoken of in the singular. Although the singular itself could be conceived 'generically', the distinctive marking of the presbyters and deacons consistently in the plural strictly disproves such a concept and speaks 
subordinate to the bishop, while other believers were to be subordinate to all the Church's servants: "Pay attention to the bishop, in order that God may pay attention to you. I am ransom on behalf of those who are obedient to the bishop, presbyters, and deacons." 10 It is possible to speak of a truly hierarchical model of Church organization, not only because of the vertical relations within the bishop - presbyters - deacons triad, but also within the whole structure of relationships within the local Church. It is also clear that the presbyters possessed wider powers than deacons, as suggested, for instance, in this call to them: "You must not do anything without the bishop and the presbyters." 11

This certainly does not mean that the relationships between the individual groups of believers in the Christian Church communities were primarily based on subordination. The epistle of Barnabas implies that they originated primarily from loving gratitude: "You shall love as the apple of your eye everyone who speaks the word of the Lord to you." 12 In addition, Ignatius calls for devoted obedience of believers to one another; in this context, we cannot talk about a one-way "pyramidal" idea of obedience: "Be subject to the bishop and to one another, as Jesus Christ in the flesh was to the Father, and as the apostles were to Christ and to the Father, that there may be unity, both physical and spiritual."13 Already the very first of Peter's epistles broadens the scope of relationships of proper subordination among the members inside the Church: "In the same way, you who are younger must accept the authority of the elders. And all of you must clothe yourselves with humility in your dealings with one another, for 'God opposes the proud, but gives grace to the humble.' Humble yourselves therefore under the mighty hand of God, so that he may exalt you in due time." ${ }^{14}$ Such a concept obviously anticipates the monastic tradition of the living virtue of Christian humility (humilitas).

in favour of monarchical interpretation. This is also evidenced by the circumstances of the time, for Ignatius already counts on the monarchist office of the bishop in the second decade of the (second) century, and Polycarp of Smyrna was already the bishop of his Church community." - H. von Campenhausen: Aus der Frühzeit des Christentums. Studien zur Kirchengeschichte des ersten und zweiten Jahrhunderts. Tübingen 1953, p. 209.

${ }^{10}$ IgnPol. 6:1a.

${ }^{11}$ IgnMagn. 7:1a

12 Bar. 19:9b.

13 IgnMagn. 13:2.

141 Pet. 5:5-6. "Reprehension of the younger ones means only one sentence. Despite the fact the 'younger' are stated in connection with the admonitions of the presbyters, there is no reason to believe that they would form a special group with specific roles, or that it would mean the whole Church community in relation to the presbyters (which is addressed in $5 \mathrm{~b}$ ); it means the younger in the sense of age." - H. BALz, W. Schrage: Die „Katholischen“ Briefe. Berlin 1982, p. 118. 


\section{Participation of the earliest community on the appointment of the Apostle}

"You did not choose me, but I chose you."15 This is how Jesus in the fourth Gospel formulates the sovereignty of his own decision-making in relation to a matter of grave concern, namely the choice of his closest disciples. Such a strong statement reflects his consciousness of unwavering authority driven by the mission entrusted to him by his heavenly Father. In the Marcan account, in turn, the appointment of the twelve disciples reveals a further aspect in this act: that is, Jesus's creative power, resembling the very creative act of God. He appointed, or literally "made"16 his twelve closest collaborators "that they might be with him and that he might send them out to preach and to have authority to drive out demons." 17

The Lord's withdrawal to the Father did not also result in his disciples' withdrawal form this world. They are still being confronted with the conditions of earthly reality shared by all other people: "My prayer is not that you take them out of the world but that you protect them from the evil one." 18 This event launches the period of the Lord's church, or the congregation (ekklésia) of Christ's faithful, which is "constituted and organized in this world as a society (societas)." 19 However, Luke's retrospective view in the Acts of the Apostles shows that practically right at the moment of the actual birth of the Church there arises an inquiry about the authority hitherto carried out by Jesus himself. Who is now to make the key decisions regarding the life of the Church after the resurrected Lord has ceased to appear to his elected? This question becomes even more pressing in relation to issues of such grave concern as entrusting the brothers with the task of serving others.

The first test of the readiness of the Church to make decisions even in the absence of the earthly Jesus was the need to complete the body of the Twelve with somebody to replace Judas, "the one doomed to

${ }^{15}$ John 15:16a. Biblical quotations are taken from the New International Version.

16 “The word 'make' (poiein) is the Greek translation of the term used in the Scriptures to define the creative activity of God. [...]. The body of the Twelve is thus not established only as a consequence of Jesus's calling, but on the basis of his action, in which he creates a new reality with the divine power." - W. KirschläGER: Die Anfänge der Kirche. Eine biblische Rückbesinnung. Graz-Wen-Kln 1990, pp. 126-127.

$17 \mathrm{Mk}: 14-15$.

18 Jn 17:15.

${ }^{19}$ Cf. CIC/1983, can. $204 \S 2$. 
destruction." 20 The necessity to make this step was anticipated by Simon Peter, whom - according to Luke - the Lord entrusted with the special mission to strengthen his brethren. ${ }^{21}$ Peter is also the one who determines the required skills of the candidate: "Therefore it is necessary to choose one of the men who have been with us the whole time the Lord Jesus was living among us, beginning from John's baptism to the time when Jesus was taken up from us. For one of these must become a witness with us of his resurrection." 22 The actual suitable candidates are not chosen by Peter, but by a community of ca. hundred and twenty brethren ${ }^{23}$ based on the general criteria defined by Peter. However, the last word should have the resurrected Lord himself; therefore, the final selection between the two candidates in the final round has the form of casting lots: "So they nominated two men: Joseph called Barsabbas (also known as Justus) and Matthias. Then they prayed, 'Lord, you know everyone's heart. Show us which of these two you have chosen to take over this apostolic ministry, which Judas left to go where he belongs.' Then they cast lots, and the lot fell to Matthias; so he was added to the eleven apostles." 24 This whole process shows both Peter's leading role, as well as the capacity of the emerging Christian community to make the choice. Nevertheless, it is still the sovereign decision of the exalted Lord: ultimately, if two candidates had been chosen for the final selection, possible quarrels leading to divisions might have ensued and so they needed to be prevented. ${ }^{25}$

Allowing the intervention of the higher power (vis maior) in the form of casting lots to choose one particular minister of the Church was an exceptional moment in the history of the Church because it concerned the completion of the body of the Twelve. Later on, this body was not completed any more, although Luke's Acts witness the brutal power intervention through which the body lost one of his leading members, James, the brother of John. ${ }^{26}$ The circle of the Twelve soon becomes

${ }^{20}$ Cf. Jn 17:12.

21 Cf. Lk 22:32.

22 Acts $1: 21-22$.

23 Cf. Acts 1:15.

24 Acts 1:23-26.

25 "The tradition about the casting lots to fill the body of the Twelve refers to a charismatic aspect of the Christian calling as office, excluding false democratization. If a community recognizes the suitability of more than one candidate, then the lot is cast to avoid being dragged to only an occasional 'election battle' which would turn the candidates into rivals running for a 'ministry'." - R. Pesch: Die Apostelgeschichte., eukirchener-Vluyn., stfildern 2012, p. 92.

${ }^{26}$ Acts $12: 1-2$. 
a firm part of the ecclesiological reflection, ${ }^{27}$ and one of the key elements of stability and identity of the Church: "The wall of the city had twelve foundations, and on them were the names of the twelve apostles of the Lamb." 28

\section{Participation of the primitive Jerusalem Church in the appointment of the Deacons}

In the decision-making process related to the need to appoint the seven ministers of the table, namely, the deacons, the key role is that of the apostles, who - in Luke's books - are only the members of the Twelve: "So the Twelve gathered all the disciples together and said, 'It would not be right for us to neglect the ministry of the word of God in order to wait on tables. Brothers and sisters, choose seven men from among you who are known to be full of the Spirit and wisdom. We will turn this responsibility over to them and will give our attention to prayer and the ministry of the word."' 29 Again we encounter a sense of trust in the community of the faithful, whom the apostles consider capable of discerning the desired activity of the needed "Spirit of wisdom". One cannot ignore the fact that the establishment of the diaconate refers to the period after the sending of the Spirit who - according to Luke's account - penetrates all the Church, directs all her decisions and safely leads the footsteps of all her ministers. Moreover, the community of the faithful who judges the suitability of the candidates had already grown large in numbers: the last concrete figure prior to the communal discernment of the candidates' charismata talks about five thousand members, ${ }^{30}$ but even after that "more and more men and women believed in the Lord and were added to their number" 31 and "the number of disciples was increasing." 32

The process of decision making delegated by the apostles onto the congregation of the Church was carried out by means of a selection:

27 "After James's martyrdom, such a requirement was no longer put forward. This means that the Twelve have their own irreplaceable significance as a constant value." H. von CAmpenhausen: Kirchliches Amt und geistliche Vollmacht in den ersten drei Jahrhunderten. Tübingen 1953, p. 17.

${ }_{28}$ Rev 21,14.

${ }^{29}$ Acts $6,2 \mathrm{~b}-3$.

30 Cf. Acts 4:4.

31 Cf. Acts 5:14.

32 Cf. Acts 6:1. 
"This proposal pleased the whole group. They chose Stephen, a man full of faith and of the Holy Spirit; also Philip, Procorus, Nicanor, Timon, Parmenas, and Nicolas from Antioch [...]. They presented these men to the apostles, who prayed and laid their hands on them." 33 The community of brethren in their collective decision making safely discerned the charismata the candidates had; and the selection process, actually only sealed the suitability of those whose names were inspired by the Spirit Himself. The apostles themselves then laid hands on them to pass on the fullness of the Spirit which they possessed. ${ }^{34}$ This understanding of the entire process of appointing the Seven prevents the reduction of the whole event to a mere tool used for solving the practical problems related to portioning out wealth to the Hellenistic widows. ${ }^{35}$ It is thus fitting that the Church, based on the subsequent centuries of theological reflection, feels obliged to treat the Sacrament of Ordination as a divine institution in its three-storeyed form whose lowest type is that of the diaconate: "The orders are the episcopate, the presbyterate, and the diaconate." ${ }^{36}$ Certainly, the immediate content of this sacramental diaconate does not include the initial table ministry as it is historically documented by Luke. In fact, soon after that, in the middle of the 2nd century AD, Justin the Martyr in his Apology provides a testimony about the ministry of the deacons: "And when the president has given thanks, and all the people have expressed their assent, those who are called by us deacons give to each of those present to partake of the bread and wine mixed with water over which the thanksgiving was pronounced, and to those who are absent they carry away a portion." ${ }^{37}$

A stable diaconate in the Church was already known to Paul in its relation to the episcopate. In his ultimate epistle that bear an immediate seal of Paul's direct authorship, that is, in the Epistle to the Philippians, Paul and Timothy address their salute "to all God's holy people in Christ Jesus at Philippi, together with the overseers and deacons." ${ }^{38}$ However, this is the only such passage where it is safe to say that Paul personally mentions these

33 Acts 6:5-6.

34 "Prior to this event, all seven had already been filled with the Holy Spirit. Their authority, however, is derived from the Twelve, established by Jesus himself. The response to the question what the Twelve mediates when laying down their hands is the legitimacy of the appointment and authorization. People of uncertain charisma are not called here, because the holders of the diakonia are properly (rite) appointed." - K. Berger: Kommentar zum Neuen Testament. Gütersloh 2011, p. 434.

35 Cf. Acts 6:1.

${ }^{36} \mathrm{CIC} / 1983$, can. $1009 \S 1$.

${ }^{37}$ Apologia prima 65,7 - in: J.-P. Migne: Patrologiae cursus completus. Series graeca. Vol. 161, pp. 427-428.

38 Phil 1:1b. 
spiritual ministers designated by their specific function. ${ }^{39}$ In other passages of Paul's letters, especially in the First Letter to the Corinthians, Paul deals with the charismata, some of which have the potential which is required for the exercise of the stable ministries in the Church, for instance, directing the Church, literally its steering (kybernésis). ${ }^{40}$ It seems obvious that those in the church communities who showed the gift of this capacity later belonged amongst the candidates for permanent appointments. Nevertheless, it is impossible to find out how and by whom this discerned charisma of theirs was acknowledged by the Church as suitable for the ministry. We may assume that this discernment and decision making was a matter of the entire community of the faithful and all of them were present. The influence of the actual apostle was so evident that a major role must have been given to the approbation of these ministers from their side, especially in cases where the appointment of new ministers was being decided. Subsequently, he and his collaborators laid down his hand on them.

\section{Participation of charismatics according to Didache}

The pairing of the ministry of the bishop and deacons can further be found in the non-biblical work called Didache, which most probably comes from the turn of the 1 st and 2nd Christian centuries. ${ }^{41}$ The author of the work deals mainly with the disciplinary issues concerning the wandering charismatics seen as apostles and prophets. Some of them later

39 "If both titles are laid next to each other, which prevents the possibility of them being the same person, one may assume that they originally come from the same group; later, however, some went on to become superiors over the others as supervisors and heads, while the scope of authority of the others was gradually limited to auxiliary activities. Given the fact, that the Letter to the Philippians is the last letter written by Paul himself and the church community there is amongst the oldest he established in Greece, the development seems absolutely natural." - C. WIEzsÄCKer: Das apostolische Zeitalter der christlichen Kirche. Tübingen - Lipzig 1902, p. 619.

40 Cf. 1 Cor 12:28.

41 "Ever since a complete copy of the Didache was first discovered in 1873, widespread efforts have been undertaken to demonstrate that the framers of the Didache depended upon a known Gospel (usually Matthew, Luke, or both) and upon one or more Apostolic Fathers (Barnabas, Hermas, and/or Justin Martyr). In more recent times, however, most scholars have pushed back the date of composition to the late first or early second century and called into question dependency upon these sources." - A. Milavec: "Synoptic Tradition in the Didache Revisited." In: Journal of Early Christian Studies. Journal of the North American Patristic Society, Cincinnati, 11, 4/2003, pp. 443-480, p. 443. 
settled in some of the church communities and acquired the position of teachers of the Christian doctrine. Over and over again, the author of Didache calls for examining the sincerity of the intention and selflessness of these persons and other newcomers into the church communities. However, this also entails gradual decadence and crisis of the institution of the prophets.

At first, the prophets, of whom Didache speaks, are travelling charismatics, who come to the individual Churches, briefly staying there and then usually leaving. They are treated with generous Christian hospitality in the communities, but there is a danger that the helpfulness could be misused: "Now concerning the apostles and prophets (apostolón kai profétón), deal with them as follows in accordance with the rule of the gospel. Let every apostle who comes to you be welcomed as if he were the Lord. But he is not to stay for more than one day, unless there is need, in which case he may stay another. But if he stays three days, he is a false prophet." ${ }^{42}$ The Didachist presents here, as travelling and visiting harbingers, a couple of apostles and prophets. The mentioned apostles indeed do not belong among the twelve included in the title itself; for these apostles it is impossible to identify any specific symbol, which would significantly distinguish them from similarly travelling prophets. ${ }^{43}$ This is also evident from the possible confusion of the apostle with a false prophet: "And when the apostle leaves, he is to take nothing expect bread until he finds his next night's lodging. But if he asks for money, he is a false prophet." 44 Among the twelve apostles stated in the heading and travelling apostles, there is, therefore, no imminent connection..$^{45}$

${ }^{42}$ Did. 11:3-5. "The term apostles is not theologically further specified, as their way of life is at the centre of attention. Their field of activity does not open for them in the established Church communities, but during missionary activities. Didache was written at the end of the 1st century and their existence at that time is therefore a surprising or even anachronistic phenomenon, and the 'rudiment from the earlier age' and, unlike other sources, their very concept does not relate to the early period." - U. HeckeL: Hirtenamt und Herrschaftskritik. Die urchristlichen Ämter aus johanneischer Sicht., eukirchenVluyn 2004, p. 30.

43 "The verses 11:3 and 11:4-6 also talk about traveling apostles. The apostle (apostolos) does not mean the 'apostle of Jesus Christ' as the witness of the Resurrected, as presumed by Paul and Luke. Rather, we are dealing here with the concept of the apostle, which we find in the New Testament only in Paul's opponents in the second letter to the Corinthians; these are apostles who have received empowerment not directly from Christ, but through the Spirit." - F. Hahn, H. Klein: Die frühchristliche Prophetie. Ihre Voraussetzungen, ihre Anfänge und ihre Entwicklung bis zum Montanismus. Eine Einführung. Neukirchen-Vluyn 2011, p. 135.

${ }^{44}$ Did 11:6.

45 "In Didache, it is a general terminology that does not yet show the technical features of a specifically Christian vocabulary. It was only later, when the Didache writing 
The attitude towards money is the distinguishing sign of a true prophet: "But if anyone should say in the spirit, 'Give me money' or anything else, do not listen to him. But if he tells you to give on behalf of others who are in need, let no one judge him." 46 In fact, a true prophet cannot even be judged: "Also, do not test or evaluate any prophet who speaks in the spirit (en pneumati), for every sin will be forgiven, but this sin will not be forgiven." ${ }^{47}$ Unlike teachers, prophets are able to talk in the Spirit; it is their very own charisma, and judging God's action in them would mean judging the Spirit itself. Here we also encounter the historically first attempt to give exact content to Jesus's statement: "Therefore I tell you, people will be forgiven for every sin and blasphemy, but blasphemy against the Spirit will not be forgiven." ${ }^{48}$ In the first letter to the Thessalonians Paul calls for respect for the authentic gifts of prophecy, but at the same time he instructs the Christian community as a whole to recognize the authenticity of the content of any prophecy: "but test everything; hold fast to what is good." 49

A parallel development here was the inner consolidation of the local churches. The faithful are encouraged to find out the candidates for the episcopacy and diaconate in the heart of their communities: "Appoint, therefore, for yourselves, bishops and deacons worthy of the Lord, men meek, and not lovers of money, and truthful and proved; for they also render to you the service (leiturgia) of prophets and teachers." 50 The charismatics, however, had a higher prestige, therefore an admonition was appropriate: "Therefore do not despise them, for they are your honoured ones, together with the prophets and teachers." ${ }^{51}$ The appointment of

was shielded with the authority of the twelve apostles, through the additionally supplemented heading." - G. G Blum: Tradition und Sukzession. Studien zum Normbegriff des Apostolischen von Paulus bis Irenäus. Berlin-Hmburg 1963, pp. 25-26.

46 Did 11:12.

47 Did 11:7.

${ }^{48}$ Matt. 12:31.

491 Thess. 5:21. "When Paul warns the Thessalonians against the uncritical acceptance of the prophetic words (1st Thess. 5:20 et seq.), urging them to find the skills, resp. the authority of the prophets and teachers. By this he certainly does not mean holding an official process or a democratic vote. It is rather necessary that the charismatic's activity is subject to certain revisions (check) and acceptance on the part of Christian communities. Prophets and teachers are not only supposed to have the internal regulation of their charismatic annunciation, but they should also have an external correction through the authority of reviewing community members." - J. MüHLSTEIGER: "Zum Verfassungsrecht der Frühkirche." In: Tradition - Wegweisung in die Zukunft. Festschrift für Johannes Mühlsteiger zum 75. Geburtstag. Eds. K. BReitsching, W. ReEs. Berlin 2001, pp. $780-781$.

50 Did 15,1a.

${ }^{51}$ Did 15:2. 
these ministers was a shared responsibility of the entire community of the faithful: this is witnessed by the call the author of the Didache addresses to all the readers of the work as members of those local churches which were to appoint these ministers. It is probable that the bishops and deacons were appointed by election which, however, should not be mistaken for a democratic procedure where the only criterion is the majority of votes for a particular candidate. Collective church corporations in the following centuries developed a rather meritocratic manner of dealing with the individual votes on the principle of the dominance of sanior pars over the maior pars. However, this system was not very effective, for example, in the case of the election of the bishops. ${ }^{52}$

Apart from the election of the ministers of the Church, Christian Antiquity also knew acclamation, a spontaneous exclamation of the people, which for instance elevated St Ambrose of Milan to the See of the Bishops. The Christian East went on to practice also the elections of the presbyters, however, this was not possible without an intervention of canonically appointed church hierarchy. ${ }^{53}$ The reformation Churches appoint their ministers primarily by election, as it is for instance formulated in the Second Helvetic Confession (Confessio Helvetica posterior): "[...] let them be carefully chosen by the Church or by those delegated from the Church for that purpose in a proper order without any uproar, dissension and rivalry." ${ }^{4}$ In the Churches coming from the Reformation one needs to confront the tendencies reducing collective decision making to mere election procedure..$^{55}$

52 "The canonists who did not trust the mere prevalence of the number of voters would propagate a 'healthier' law of the canonical capitula, in their longing for a 'good choice' against the 'law of the majority'. [...] However, this caused long-standing disputes and long periods of sedisvacation whose costs had to be paid by the diocese." J. Gaudemet: Storia del diritto canonico. Ecclesia et Civitas., inisello Balsamo: Edizioni San Paolo, 1998, p. 472.

53 "Between 11th and 15th centuries in Russia, priest candidates were chosen by the people in the church community using an election procedure. The chosen candidate was then introduced to the bishop for examination and chirotonia (ordination)." J. JAcoš: Cirkevné právo. Prešov 2006, p. 119.

54 Second Helvetic Confession, art. 18, v. 7.

55 "Even in the reformed tradition, the presbyter is not a mandatory of the people as the legal sovereign. The selection principle means the recognition of Christ's mandate, the only sovereign of His people. The people, inspired by the wisdom of the Holy Spirit, authorizes some people from its middle where he recognized the necessary charismas to keep the originality of Christ's rights in the Church." - P. FILIPI: Církev a církve. Kapitoly z ekumenické ekleziologie. Brno 2000, p. 117. 


\section{Communitarian participation in the application of Church discipline}

Once the community of the faithful with legitimate superiors has been established, it should also develop procedures that lead to appropriate discipline in accordance with the dignity of the Christian vocation. Amongst the four Evangelists, Matthew reports a series of Jesus's logia with the different degrees of disciplinary procedure, as it should be practiced in local churches, that is, the addressees of the Gospel. It is a short series of statements, commonly known as "fraternal admonishing" (correctio fraterna). In reality, these logia go far beyond the private relational framework. This framework is the basis only in the first act: "If your brother or sister sins, go and point out their fault, just between the two of you. If they listen to you, you have won them over." ${ }^{\text {" }}$ This statement has - unlike the others - a parallel verse in the Gospel of Luke. ${ }^{57}$ Apart from the key moment of turning your brother away from sin, an important element in relation to the dynamic of the entire Christian community is the discreet nature of such a process which does not expose the sinner to public shame..$^{58}$

In fact, only the potential second phase arrives at the point where external witnesses are to be called to take part in the process: "But if they will not listen, take one or two others along, so that "every matter may be established by the testimony of two or three witnesses." ${ }^{9}$ This is an allusion to the law on witnesses found in Deuteronomy which stipulates that for a just sentence two or three testimonies are needed, ${ }^{60}$ although Paul himself already testifies the domestication of this principle in the early Church without stressing its sacred origin. ${ }^{61}$ The same may be found in the letters addressed to Timothy and Titus which put particular emphasis

56 Mt 18:15.

${ }^{57}$ Lk 17:3.

58 "The privacy of the initial contact allows the sin to be dealt with without any need for wider awareness or for public shaming. Insofar as this is possible, the privacy of the initiative protects the dignity of the person, even at the point of serious sin. The matter is to be dealt with at the lowest possible effective level and the circle of knowledge restricted as much as possible." - J. Nolland: The Gospel of Matthew. A Commentary on Greek Text. Bletchley 2005, p. 746.

59 Mt 18:16.

${ }^{60}$ Dt 19,15 .

61 "A similar allusion occurs in 2 Cor 13.1; Paul neither quotes the injunction as from scripture nor as a word of the Lord. Rather, he assumes that the injunction requiring two or three witnesses is common knowledge among the Corinthians." Sт. H. Brooks: Matthews Community. Sheffield 1987, p. 101. 
on the honoured standing of the ministers of the Church. Those are to enjoy special protection of their honour by not accepting unsubstantiated denunciations: "Do not entertain an accusation against an elder (presbyter) unless it is brought by two or three witnesses." ${ }^{2}$ The canonical principle testis unus, testis nullus, which does not allow the sufficiency of a singular witness has been exercised in the Church right from the beginning.

In the third phase, the individual tort becomes an issue for the entire community of the local church. Selected witnesses who were to add the due gravity of the sinner's conversion as a mediating instance are no longer sufficient: "If they still refuse to listen, tell it to the church (ekklésia); and if they refuse to listen even to the church, treat them as you would a pagan or a tax collector." 63 The word "church" used here is to be understood as a gathering of the members of the local church, whose primary responsibility in such case is not passing a sentence on somebody, but trying to persuade the sinner to refrain from such acts in the future. In fact, only the subsequent unrepented stubbornness leads the community to expel the sinner, because a perverse conduct is not just a private matter, but a serious offence threatening the healthy growth of the entire Christian community. ${ }^{64}$ A strong Judeo-Christian bias of the Gospel of Matthew is reflected in referring to two categories excluded from God's salvific action, that is, the pagans and the tax collectors. A sinner that does not repent and does not listen to the voice of the church congregation acting as the institution of judgement. ${ }^{65}$

From the forensic point of view, that is, if the whole procedure is to be taken as a schematic sketch of the different phases of the court proceedings, it is necessary to stress that the expulsion from the life of the community is presented here only as the extrema ratio, which is activated after the other means of pastoral activity have been exhausted. The excommunication thus represents a self-purgative mechanism of the church community, not an act of retaliation against the offender. What is activated here is both pastoral attitude towards an incorrigible offender, but also

621 Tim 5:19.

${ }_{63}$ Mt 18:17.

64 "The offender, faced by the disapproval of the whole local disciple community, ought surely to recognize that this was not just a personal grievance on the part of the initiator. Anyone who is not willing to accept such united testimony may then properly be regarded as no longer a fit member of the community." - R. T. FranCE: The Gospel of Matthew. Grand Rapids 2007, p. 693.

65 'From the Christian point of view, the term 'pagan' should only have meaning in a religious sense. In the case of the tax collector, it is a person imaginable solely within the community of the Jewish community." "W. Trilling: Das wahre Israel. Studien zur Theologie des Matthäusevangeliums. Leipzig 1975, p. 115. 
towards the community, since it cannot tolerate a type of conduct which could cause irreparable damage in its own interior. ${ }^{66}$

The logia about brotherly admonishing reported by Matthew served as inspiration for the disciplinary orders also at a time when the majoritarian church developed into a form which demanded punishing offenders on the vertical level, without the presence of the other representatives of the church community, let alone with the possibility to discuss the crime and punishment together with the superiors. In their practice, however, the religious communities could keep at least the immediate inspiration of Jesus's words, as it is testified in the Rule of Benedict: "If a brother is found to be obstinate, or disobedient, or proud, or murmuring, or habitually transgressing the Holy Rule in any point and contemptuous of the orders of his seniors, the latter shall admonish him secretly a first and a second time, as Our Lord commands (Matt. 18:15). If he fails to amend, let him be given a public rebuke in front of the whole community. But if even then he does not reform, let him be placed under excommunication (excommunicationi subiaceat), provided that he understands the seriousness of that penalty." 67

The participation of the whole community in the act of expulsion of the offender from its centre had already been testified by Paul in the New Testament. He urged the Christians in the Corinthian community to take this step in order to get rid of one of his members who "is sleeping with his father's wife." 68 In this case, the declaration of the excommunication is based on the apostle's written warrant: "For my part, even though I am not physically present, I am with you in spirit. As one who is present with you in this way, I have already passed judgment in the name of our Lord Jesus on the one who has been doing this. So when you are assembled and I am with you in spirit, and the power of our Lord Jesus is present, hand this man over to Satan for the destruction of the flesh, so that his spirit may be saved on the day of the Lord." ${ }^{69}$ Since it is a transgression which Paul considers extraordinarily grave, the community of the faithful is to be present at the moment of imposing the sentence. The effects of the sanction imposed by the Church, however,

66 "It is unclear, hat the transgression of the brotherhood involved. Although one may not determine the sin with precision, the pericope still has something to say. It shows that Matthew reflected the ordinary court forms, however, only as long as they could - ith the use of spiritual and pastoral tools, i.e. admonishing - onvince the brother who erred." - R. Sевотт: Fundamentalkanonistik. Grund und Grenzen des Kirchenrechts. Frankfurt am Main 1993, p. 170.

${ }^{67}$ Regula Benedicti 23, 1-4.

68 Srov. 1 Cor 5:1.

691 Cor $5: 3-5$. 
do not anticipate the ultimate fate of the sentenced person: in fact, that will be made clear "on the day of the Lord." Nevertheless, the community of the faithful must defend itself and Paul leads them to find courage together to undertake such a step: "Expel the wicked person from among you." 70

In a similar manner, if the case demands it, Paul also urges to be lenient: "The punishment inflicted on him by the majority is sufficient. Now instead, you ought to forgive and comfort him, so that he will not be overwhelmed by excessive sorrow." 71 Paul's inspiration remained present in the Church also at times when the sanction of excommunication was not necessarily used sparingly, as it is testified in the Constitution Cum in multis of the First Council of Lyon (1245), which characterises the expulsion from the community of the Church as a "curative (medicinalis), not lethal" punishment, which is meant to "correct, not annihilate."

\section{Conclusion}

Since the very beginning, the Church has been permeated with mutual communication of the faithful. Their main goal was to reach decisions which respect the will of the resurrected and exalted Lord. Initially, procedures were not as important as the basic attitude of respectful, mutual love: "Submit to one another out of reverence for Christ." 73 Also, love was to lead the congregation of the Church to all the inevitable decisions regarding disciplinary transgressions of the individual faithful. The concrete forms of dealing with the material and personal decisions in the various church communities are scarcely documented in the available sources. Nevertheless, it is clear that all members of the church communities were incorporated into the decision-making process on the basis of their capacities and charismata. However, the leading role must have had especially those who were understood as the "columns of the Church".

\footnotetext{
701 Cor 5:13b.

712 Cor $2: 6-7$.

${ }^{72}$ Cf. G. Alberigo (et al.): Conciliorum Oecumenicorum Decreta. Bologna 2002,

${ }^{73}$ Eph 5:21.
} p. 291. 


\section{Bibliography}

Alberigo G. et al.: Conciliorum Oecumenicorum Decreta. Bologna 2002.

Balz H., Schrage W.: Die „Katholischen“ Briefe. Berlin 1982.

Berger K.: Kommentar zum Neuen Testament. Gütersloh 2011.

Blum G. G.: Tradition und Sukzession. Studien zum Normbegriff des Apostolischen von Paulus bis Irenäus. Berlin-Hamburg 1963.

Brooks St. H.: Matthews Community. Sheffield 1987.

Campenhausen H. von: Aus der Frühzeit des Christentums. Studien zur Kirchengeschichte des ersten und zweiten Jahrhunderts. Tübingen 1953.

CAmpenhausen H. von: Kirchliches Amt und geistliche Vollmacht in den ersten drei Jahrhunderten. Tübingen 1953.

Code of Canon Law. Latin-English Edition. New English Translation. Washington 2012.

Filipi P.: Církev a církve. Kapitoly z ekumenické ekleziologie. Brno 2000.

France R. T.: The Gospel of Matthew. Grand Rapids 2007.

García Martín J.: Le norme generali del Codex Iuris Canonici. Roma 1996.

Gaudemet J.: Storia del diritto canonico. Ecclesia et Civitas. Cinisello Balsamo 1998.

Grant R. M.: The Apostolic Fathers. A New Translation and Commentary. New York 1964.

Hahn F., Klein H.: Die frühchristliche Prophetie. Ihre Voraussetzungen, ihre Anfänge und ihre Entwicklung bis zum Montanismus. Eine Einführung. Neukirchen-Vluyn 2011.

Heckel U.: Hirtenamt und Herrschaftskritik. Die urchristlichen Ämter aus johanneischer Sicht. Neukirchen-Vluyn 2004.

Jacoš J.: Cirkevné právo. Prešov 2006.

KirschläGer W.: Die Anfänge der Kirche. Eine biblische Rückbesinnung. GrazWien-Köln 1990.

Migne J.-P.: Patrologiae cursus completus. Series graeca. Vol. 161. Paris 18641866.

Milavec A.: "Synoptic Tradition in the Didache Revisited." In: Journal of Early Christian Studies. Journal of the North American Patristic Society, Cincinnati, 11, 4/2003, pp. 443-480.

MüHLSTEIGER J.: “Zum Verfassungsrecht der Frühkirche." In: Tradition - Wegweisung in die Zukunft. Festschrift für Johannes Mühlsteiger zum 75. Geburtstag. Eds. K. Breitsching, W. Rees. Berlin 2001, pp. 741810.

J. Nolland: The Gospel of Matthew. A Commentary on Greek Text. Bletchley 2005.

Pesch R.: Die Apostelgeschichte. Neukirchener-Vluyn, Ostfildern 2012.

Regula Benedicti. Řehole Benediktova. Praha 1998.

Sевотт S.: Fundamentalkanonistik. Grund und Grenzen des Kirchenrechts. Frankfurt am Main 1993. 
Trilling W.: Das wahre Israel. Studien zur Theologie des Matthäusevangeliums. Leipzig 1975.

WiezsëCKer C.: Das apostolische Zeitalter der christlichen Kirche. TübingenLeipzig: Mohr-Siebeck, 1902.

WiNZELER Ch.: Einführung in das Religionsverfassungsrecht der Schweiz. Zürich 2009.

Stanislav Př́ibYl

\title{
Partecipazione dei fedeli al processo decisionale nella Chiesa
}

\begin{abstract}
Fino ad oggi, la vita della Chiesa primitiva riflette l'autenticità delle pratiche e dell'organizzazione interna. Questo articolo discute la questione della vita interna e dell'ordine delle comunità ecclesiali nei primi tempi della Chiesa. Allo stesso tempo, non mette in discussione il ruolo dei protagonisti della Chiesa, manifestatosi nelle concrete chiamate all'obbedienza dei fedeli, come testimoniano già gli scritti neotestamentari; cui corrispondeva anche l'istituzione del vescovo monarchico, secondo le lettere di Ignazio di Antiochia. Tuttavia, già negli Atti degli Apostoli di San Luca, ci sono testimonianze della partecipazione dell'intera comunità ecclesiale alla nomina dell'apostolo Matteo e dei primi sette diaconi. L'opera paleocristiana della Didache, oltre a sottolineare l'importanza dei portatori del carisma profetico, offre anche alle comunità ecclesiali alcuni criteri per la loro partecipazione al ministero di questi carismatici e per la loro valutazione. Il Vangelo di San Matteo e la prima lettera di San Paolo ai Corinzi indicano poi la partecipazione di tutti i membri delle comunità ecclesiali nell'attuazione delle necessarie misure penali richieste contro i cristiani colpevoli.
\end{abstract}

Parole chiave: Chiesa, apostolo, sacerdote, diacono, profeta, procedura, elezione, disciplina, castigo

Stanislav Př́ibyl

Participation des fidèles au processus décisionnel dans l’Église

Résumé

La vie de l'Église primitive, aujourd'hui encore, reflète l'authenticité des pratiques et de son organisation interne. Le présent article traite la question de la vie interne et de l'ordre des communautés ecclésiales aux premiers temps de l'Église. Il ne remet pas pour autant en cause le rôle des personnages de premier plan dans l'Église, un rôle qui se manifeste dans les appels concrets des fidèles à l'obéissance, comme en témoignent déjà les écrits du Nouveau Testament; à cette tendance correspondait aussi l'institution de l'évêque monarchique, selon les lettres d'Ignace d'Antioche. Cependant, déjà dans les 
Actes des Apôtres St. Luc, on peut lire des témoignages de la participation de l'ensemble de la communauté ecclésiale à la nomination de l'apôtre Matthieu et des sept premiers diacres. L'œuvre paléochrétienne de la Didaché, tout en soulignant aussi l'importance des porteurs du charisme prophétique, offre aussi aux communautés ecclésiales des critères pour leur participation au ministère de ces charismatiques et leur évaluation. L'Evangile de St. Matthieu et la première lettre de St. Paul aux Corinthiens indique ensuite la participation de tous les membres des communautés ecclésiales à l'exécution des mesures pénales nécessaires contre les chrétiens coupables.

Mots-clés : Église, apôtre, prêtre, diacre, prophète, procédure, élection, discipline, punition 